\title{
Graft versus host disease
}

INSERM

\section{Source}

INSERM. (1999). Orphanet: an online rare disease and orphan drug data base. Graft versus host disease. ORPHA:39812

Acute graft-versus-host disease (GVHD) occurs after allogeneic hematopoietic stem cell transplant and is a reaction of donor immune cells against host tissues. Activated donor $T$ cells damage host epithelial cells after an inflammatory cascade that begins with the preparative regimen. 